\title{
Prima facie reasons to question enclosed intellectual property regimes and favor open-source regimes for germplasm
}

\section{[version 1; peer review: 3 approved, 1 approved with}

\section{reservations]}

\author{
Madeleine-Thérèse Halpert ${ }^{1,2}$, M. Jahi Chappell(i2,3 \\ ${ }^{1}$ Falk School of Sustainability, Chatham University, Gibsonia, PA, 15232, USA \\ ${ }^{2}$ Institute for Agriculture and Trade Policy, Minneapolis, MN, 55404, USA \\ ${ }^{3}$ Centre for Agroecology, Water, and Resilience, Coventry University, Ryton-on-Dunsmore, Coventry, CV8 3LG, UK
}

\author{
V1 First published: 17 Mar 2017, 6:284 \\ https://doi.org/10.12688/f1000research.10497.1 \\ Latest published: 17 Mar 2017, 6:284 \\ https://doi.org/10.12688/f1000research.10497.1
}

\begin{abstract}
In principle, intellectual property protections (IPPs) promote and protect important but costly investment in research and development. However, the empirical reality of IPPs has often gone without critical evaluation, and the potential of alternative approaches to lend equal or greater support for useful innovation is rarely considered. In this paper, we review the mounting evidence that the global intellectual property regime (IPR) for germplasm has been neither necessary nor sufficient to generate socially beneficial improvements in crop plants and maintain agrobiodiversity. Instead, based on our analysis, the dominant global IPR appears to have contributed to consolidation in the seed industry while failing to genuinely engage with the potential of alternatives to support social goods such as food security, adaptability, and resilience. The dominant IPR also constrains collaborative and cumulative plant breeding processes that are built upon the work of countless farmers past and present. Given the likely limits of current IPR, we propose that social goods in agriculture may be better supported by alternative approaches, warranting a rapid move away from the dominant single-dimensional focus on encouraging innovation through ensuring monopoly profits to IPP holders.
\end{abstract}

\section{Keywords}

Agroecology, agrobiodiversity, germplasm, innovation systems, intellectual property, plant breeding, seed systems

\section{Open Peer Review}

\begin{tabular}{lcccc} 
Approval Status & $?$ & 3 & 4 \\
\hline & 1 & 2 & 3 & \\
version 1 & & $?$ & & \\
17 Mar 2017 & view & view & view & view
\end{tabular}

1. Sheryl D. Breen (D), University of Minnesota Morris, Morris, USA

2. William F. Tracy, University of Wisconsin-Madison, Madison, USA

3. Sue Farran, Northumbria University , Newcastle, UK

4. Guntra A. Aistara, Central European University, Budapest, Hungary

Ana Ruth Martinez Rizo, Central European University, Budapest, Hungary

Any reports and responses or comments on the article can be found at the end of the article. 


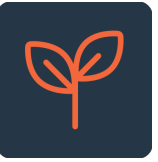

This article is included in the Agriculture, Food

and Nutrition gateway.

\section{Corresponding author: M. Jahi Chappell (mjahi@umich.edu)}

Competing interests: MJC sits on the Board of Directors of the Open Source Seed Initiative (OSSI). At the time of the conception and initial drafting of this paper, MJC and MH both worked for the Institute for Agriculture and Trade Policy (IATP). IATP helped found OSSI and is a partner organization. The work here reflects the analysis performed by MH and MJC, and does not necessarily reflect the views of OSSI or IATP.

Grant information: The author(s) declared that no grants were involved in supporting this work.

Copyright: $\odot 2017$ Halpert MT and Chappell MJ. This is an open access article distributed under the terms of the Creative Commons Attribution License, which permits unrestricted use, distribution, and reproduction in any medium, provided the original work is properly cited. Data associated with the article are available under the terms of the Creative Commons Zero "No rights reserved" data waiver (CC0 1.0 Public domain dedication).

How to cite this article: Halpert MT and Chappell MJ. Prima facie reasons to question enclosed intellectual property regimes and favor open-source regimes for germplasm [version 1; peer review: 3 approved, 1 approved with reservations] F1000Research 2017, 6:284 https://doi.org/10.12688/f1000research.10497.1

First published: 17 Mar 2017, 6:284 https://doi.org/10.12688/f1000research.10497.1 


\section{Introduction}

Given the challenges of sustainably providing food security for the present and future human population, it is often asserted that largescale, technology-intensive agricultural innovation is necessary now, more than ever (Beddington, 2010; Monsanto, 2015). Indeed, there seems to be near consensus, from corporations to social movements, that "business as usual is not an option" (IAASTD, 2009; Joubert, 2016; Unilever, 2016). This sense of urgency is embraced by many agrifood corporations, who often put forward their products and services as key contributions to help society innovate into a better future. Leaving aside the flaws in this framing of the challenges facing us (see e.g., Lappé \& Collins, 2015), large multinational agricultural corporations are, in a certain sense, uniquely placed to lead in this innovation process: they increasingly dominate all aspects of the food system, including seeds (Howard, 2016). Further, within the area of agricultural inputs, these corporations have been able to assure their continued prominence through the dominant intellectual property regime (IPR), particularly patents on seeds. Whether the approaches to IPR embraced by such actors is to the (public) good in the face of today's large-scale problems is the topic of this paper.

The underlying claim made (especially, but not solely) by large agricultural corporations in support of intellectual property protections (IPP) is that "locking up" innovations behind patents is a necessary mechanism to ensure continued innovation. The ex post ("after-the-fact") inefficiency that occurs when IPPs prevent other innovators from building on new technologies is widely recognized, but is considered part of a "profitable bargain for society" (Moschini, 2010). The argument goes that in an area that involves high research costs, the net social good of innovations spurred by the potential monopoly protection of patents is greater than what is lost due to patents' restrictions.

This logic is widespread and broadly accepted, and recent decades have seen an increase in the importance of IPPs in shaping seed systems around the world, particularly in the U.S. (Kloppenburg, 2004; Luby \& Goldman, 2016). Given the challenges of providing both food security and environmental sustainability in agriculture, agricultural corporations argue that innovation-and therefore patents-will only become more important yet.

But what if patents pose more of an impediment than an aid to addressing current challenges? The actual balance of costs and benefits realized from intellectual property typically goes unquestioned. So it is possible, prima facie, that patents and similar elements of dominant global IP systems are unnecessary, and perhaps even inimical, to the development of socially-beneficial innovations in agriculture. Furthermore, alternative approaches may be equally or better able to support innovation through mechanisms that decrease or eliminate the ex post inefficiency (Cimoli et al., 2014). This paper explores these ideas, specifically with reference to germplasm, based on an analysis of existing and theoretical dynamics in agriculture and innovation.
Intellectual property protections for plants in the U.S. and in international agreements

Since the 1960s, a jumble of international governing organizations have attempted to regulate IPPs for plant genetic resources. During this time, significant pressure by individual governments and international institutions has been exerted to adopt what could be called a "global IPR", which has been "developed principally in the Western legal context... principally a U.S. utilitarian approach" (Forsyth, 2016; see also Henry \& Stiglitz, 2010).

The "utilitarian" innovation system of the U.S. is based on an approach whereby ideas and materials are putatively owned by individual entities, excluding all others from using such "intellectual property" without permission. Within this approach, three primary forms of IPP governing plants and plant genetic resources have been developed over the past century: plant patents; Plant Variety Protection certificates; and utility patents.

The 1930 Plant Patent Act allowed breeders to patent plant varieties that reproduce asexually (i.e., without seeds), protecting putative owners of IP while sidestepping controversies around seed saving practices (Heald \& Chapman, 2011). Starting from 1970, sexually reproduced plants were also "protected" through Plant Variety Protection (PVP), providing that the varieties could be determined to be novel, distinct, and uniform. PVP certificates included two important exceptions: a breeders' exception allowing the use of protected varieties for non-commercial research and the development of varieties not essentially derived from the protected variety; and a farmers' exception allowing seed saving for personal use (Heald \& Chapman, 2011; Pardey et al., 2013). The third form of IPP in the U.S. has its origin in the 1980 U.S. Supreme Court case Diamond vs. Chakrabarty. This case (and subsequent rulings) asserted that utility patents were applicable to plant varieties, and even genetic sequences in certain cases (Van Dooren, 2008). Unlike PVPs, the extension of utility patenting to plant and genetic materials involved no exceptions for seed saving, research, or other breeding activities. Certain forms of "dual protection" are also possible, combining different kinds of patents, or a PVP certificate and a utility patent (Pardey et al., 2013). Additionally, large commercial breeders have made use of contracts, laws protecting trade secrets, intraindustry-regulation and enforcement ("private ordering") to exclude others from accessing their innovations (Butruille et al., 2015), and to reinforce formal modes of IPP. In some cases this has made IPP restrictions significantly more severe (Elkin-Koren, 2005; Kloppenburg, 2014).

Many policies at the international level have paralleled the U.S.'s trajectory. For example, the International Union for the Protection of New Varieties of Plants (UPOV) establishes requirements that varieties to be protected are novel, distinct, uniform, and stable. While it had included farmers' and breeders' exceptions similar to that of PVPs, the most recent version of the agreement made these exceptions optional (Salazar et al., 2007; Van Dooren, 2008). Meanwhile, the World Trade Organization requires all member 
nations to have some form of IPP for plants through the Agreement on Trade-Related Aspects of Intellectual Property Rights (TRIPS). Under TRIPS, countries technically have the option to develop their own IPP systems, which could potentially support alternatives to the dominant global IPR (Kloppenburg, 2010). However, in practice most countries simply adopt restrictions descending from the U.S./Western approach.

At times, however, international agreements have included approaches differing from this pattern. Some agreements have attempted to regulate plant genetic resources as common heritage, to address the uneven flow of germplasm from "developing" countries to "developed" ones, and to account for the crucial historical and continuing contributions of countless farmers to plant breeding (Aoki, 2009). While these attempts are useful for suggesting alternatives to protecting and supporting innovation, they have so far had relatively little impact, and have been significantly constrained by the dominant global IPR. For example, the International Treaty on Plant Genetic Resources for Food and Agriculture (ITPGR) established a system in which recipients of germplasm from international seed banks cannot patent any of the seeds they receive from these banks (Aoki, 2009). However, patenting germplasm or genetic materials that are subsequently derived from such multilateral system seeds or particular genes or DNA is allowed under the treaty (ibid.). This means that there is a still the opportunity for patenting entities to benefit from common heritage while refusing to share subsequent benefits (Vogel et al., 2011).

\section{Draining the pool of knowledge: Enclosing more than giving back}

While the necessity and effectiveness of IPPs, and patents in particular, are often assumed, some researchers have begun to examine the quality of these claims, especially in the context of germplasm. The pertinent question is essentially whether IPPs may limit future innovation more than they contribute to it. And patents, in particular, have been heavily scrutinized from this point of view. By granting exclusive rights of ownership to the patent holder, they are one of the most restrictive approaches to IPP, essentially allowing the owner to set the price for others to use their IP at infinity (Stiglitz, 2014). Thus,

- "What seem to be more important [than strong IPRs] are the 'opportunities,' the potential for discoveries, related to the pool of knowledge to be exploited...

- $\quad$...Patents inevitably enclose what would otherwise have been in the public domain. In doing so, not only do they impede the efficient use of knowledge, but because knowledge itself is the most important input into the production of further knowledge (innovations), they may even impede the flow of innovations," (Stiglitz, 2014).

Under Stiglitz's models using "plausible conditions," the incentives to innovation provided by patents encourages innovation initially, but ultimately does not sufficiently replace what it removes, stifling further innovation. This effect, combined with a possible underuse of existing innovations resulting from IPPs, is a dynamic that has been identified in biomedical research as the "anti-commons," by Heller \& Eisenberg (1998). In an anti-commons, "more intellectual property rights may lead paradoxically to fewer useful products for improving human health." While Heller and Eisenberg clarify that they are not speaking about the "routine underuse" of innovations that occurs under patents, their description of an anti-commons appears to fit the results of Stiglitz's model as well.

Given that agroecosystems span a wide range of cultural and environmental conditions and affect a wide variety of needs and impacts (from food security to their effects on wild biodiversity to climate change impacts), it would seem appropriate to have an innovation system that encourages greater accessibility to knowledge for a diversity of approaches and actors. Yet the current IPR appears to have contributed to the neglect of certain approaches to agriculture and plant breeding and contributed to a dearth of plant breeding PhDs (Goodman, 2002; Vanloqueren \& Baret, 2009). Further, Vanloqueren and Baret point out that practices like agroforestry that provide a number of public goods (e.g. sustainable livelihoods, resilience, and environmental quality) are based on system-level practices that are not patentable, and generate benefits over a long time period, two characteristics that strongly limit the pertinence of IPPs for boosting innovation. Such dynamics should be an object of concern; robust innovation systems ought to grant appropriate consideration to the full scope of ideas that could be socially useful (van den Hove et al., 2012).

To give a brief practical example of the dynamics at hand, one study of genetic diversity in pearl millet cultivars in India demonstrated that farmer social and management practices helped to maintain diversity and variation among local landraces, which "possess superior nutritional quality as well as higher fodder yield under severe conditions," (vom Brocke et al., 2003). This is consistent with numerous studies showing that maintenance of agrobiodiversity can significantly contribute to sustainable farmer livelihoods, resilience, and adaptability (Chappell et al., 2013). But despite these useful properties, the diversity within landraces means they are generally not distinct, uniform, and stable, as would be required for protection under global IPR (Salazar et al., 2007). Further, the restrictions of typical IPPs means farmers would not be able to legally treat protected varieties "as raw material for direct use and further improvement [which] is still the norm in many parts of the world" (ibid). Between this and the requirements of uniformity, distinctiveness, and stability, the dominant global IPR often exerts pressure to decrease diversity, and thus limit the usefulness and adaptability of our future seed supply_taking more out of the collective "pool of knowledge" than the IPPs put back.

These dynamics represent the dangers of enclosing knowledge, but we have not yet covered the evidence as to how much IPPs do incentivize further innovation, that is to say, what IPPs give back to the pool of knowledge. On the one hand, drawing from case studies in the Pacific Islands region, Forsyth \& Farran (2013) observed that "a Western IP system deflects attention from the need to support the organisations actually generating agricultural innovation in the region" (where breeding funding comes primarily from the public sector and NGOs who are not seeking patent-based returns on investment). Further, the dominant Western IPR may undermine traditions of benefit sharing and "undermine regional initiatives to promote food security through the sharing of plant 
genetic resources" (Forsyth \& Farran, 2013). In the cases they examined (and by analogy, they argue, many other "less developed countries"), prioritization of food security has generally been associated with supporting diversity, autonomy, and protection of farmers' access to seeds within alternative and traditional networks, while approaches focusing on global IPR have often accompanied a trade-oriented mentality that does not truly address the needs and particularities of local communities (Forsyth \& Farran, 2013; see similar conclusions based on research in other "less developed countries" in Chappell et al., 2013; McKeon, 2015).

However, in contrast to areas where the public sector dominates funding for plant breeding, IPPs should theoretically be responsible for significant outputs of research systems where plant breeding research is largely funded by private companies, as it is in the U.S. Heald \& Chapman (2011) examined this hypothesis in one of the most extensive empirical analyses of IPPs to date. The authors studied the relationships between diversity, PVPs, patents, and commercially available varieties for apples and 42 vegetables over the period of 1903-2004. While a substantial number of new varieties were commercialized during this timeframe (which they took to represent innovation), only $3.8 \%$ of varieties commercially available in 2004 (excluding corn) were ever subject to patents, and only $16 \%$ of patented varieties were ever commercialized, suggesting a weak connection between IPPs and innovation in this area of breeding. In other words, most of the innovation in these plants was produced independently from IPP incentives. It should be noted that in the case of corn, patenting activity was much more prominent and patented seeds were prevalent in the market. But Heald and Chapman assessed that patents in corn may represent rent-seeking more than protection for innovation. That is, patents in corn may serve to exclude others from accessing "protected" germplasm without supporting any further innovation (Heald \& Chapman, 2011).

Even if this is the case, Western-style IPP might still be justified if rent-seeking owners use what they have withdrawn from the pool of knowledge to produce even higher-quality innovations than they would have otherwise produced. That is, the "monopoly rent" they extract from patents on, say, corn varieties may not spur them to innovate by creating more varieties, but it is possible that they use their profits to come up with higher quality varieties. However, in the case of plant breeding, there are reasons to doubt that extremely high-cost patented research is worthwhile in this manner, either. For example, research on seed prices has demonstrated that transgenic traits in commercialized seed are overpriced with regard to the relative research costs and yield gains provided to farmers through conventional breeding (Goodman, 2002; Moss, 2013). In this case, IPPs may simply be enabling companies to charge prices for their IP that are actually greater than the benefits they produce (Moss, 2013). A second, if tentative, line of evidence that patents may not be driving innovation of significantly superior varieties comes from a study by Bulte et al. (2014). Their analysis of randomized control and double-blind trials in Tanzania found that differences in yield between modern and traditional cowpea varieties were wholly due to differences in farmers' management practices based on perceived differences in the varieties (as harvests were the same for farmers who received modern varieties and those who did know which type of seed they got). While this was only one study, and its results cannot be extrapolated to all modern seeds (or specifically those under IPPs), a comprehensive review by Loevinsohn et al. (2013) implies that the literature evaluating agricultural innovation is rife with similar challenges to scientific validity: they screened over 20,000 studies, and came up with only 5 that met reasonable standards of rigor (e.g., that would be capable of eliminating the confounding effects found by Bulte et al.).

In short, there is a significant lack of rigorous evidence that IPPs have led to the kind of higher-quality innovation that would justify their restrictions, much less sufficient evidence to establish that IPPs are decisively "giving back" more than they are taking from the collective pool of knowledge.

\section{Further considerations challenging contemporary dominant IPR}

Beyond the dynamics related to the "pool of knowledge," other factors may limit the appropriateness of global IPR for plant genetic resources: the connections between agriculture, plant breeding, and a number of other public goods. For example, with regards to "essential facilities"- resources that have no substitute and are fundamentally necessary for further innovation to occur-Henry \& Stiglitz (2010) argue that no broad patents, and possibly, no patents at all should be granted. They give the specific example of genetically modified foods (e.g., crops), and cite Harhoff et al.'s (2001) conclusion that patents in this area may not only not be necessary to innovation, but may hold back socially useful applications. Even those who strongly defend the use of IPPs for seeds point out at the same time that society at large benefits from broad access to plant genetic resources and the ability to save seeds (Scalise \& Nugent, 1995). The problem with broad access, according to Scalise and Nugent, is that society's benefits come at the cost of inventors, and therefore, society will see fewer important innovations by inventors and miss out on new technologies that will help feed everyone and improve general welfare. Beyond the challenges to this claim that we have already addressed, it is important to re-emphasize the large uncertainties present in evaluating the benefits of supposed innovations in plant breeding. That is: not only is the academic research on benefits of agricultural innovation lacking in rigorous and controlled studies, but as Stone et al. (2014) point out farmer decisions in many cases may be dominated by social learning (emulation) and lead to a high degree of "faddism". In their study, farmer adoption of new varieties was dominated by cues taken from what other farmers were doing, and was not meaningfully related to the qualities of each set of new seeds. This was not due to some deficiency on farmers' part; they note that "yields and profits from any given seed are highly variable", and "attributing... performance advantages that have not been truly isolated from [their] confounding factors" is ubiquitous and long-standing throughout agriculture, echoing Loevinsohn et al.'s findings. The result is that it may, in practice, be impractical and unlikely that farmers will be able to decisively identify the benefits of innovations as quickly as private actors produce them, especially without the legal right to save and select seeds themselves, creating an information asymmetry benefitting IPP holders at the cost of farmers. One might term it as a problem of a "market for persimmons," where farmers cannot 
quickly or easily distinguish the benefits of one seed versus another. (Various types of the persimmons fruit may appear similar, but need to be treated differently; cf. Akerlof (1970)).

Plant genetic resources are also tied to other public goods, such as biodiversity. For instance, agrobiodiversity affects the conservation of wild biodiversity (Chappell et al., 2013), and the loss of the former can negatively affect the latter. Therefore, if IPPs were leading to a loss of agrobiodiversity, that would be another argument against the dominant approach. Unfortunately, the degree of agrobiodiversity loss (or increase) over the past decades is difficult to measure and highly contended (Montenegro de Wit, 2015). However, the loss of small independent seed companies is more straightforward to measure, and would imply some levels of lost diversity given that larger, consolidated seed firms will have higher incentives to breed for a small amount of "elite" lines with " broad adaptability' - the capacity of a plant to produce a high average yield over a wide range of growing environments and years... [while] varieties yielding well in one zone but less in another are quickly eliminated" (Desclaux et al., 2012). With regards to seed company consolidation and IPPs, not only have the applications for plant and utility patents and PVPs risen steeply since the 1980s and 90s, but the percentage of patents and PVPs held by the top applicants has also increased (Pardey et al., 2013). Farmers have increased their reliance on purchased rather than saved seed over the same time period as consolidation has increased dramatically (Howard, 2016; Marco \& Rausser, 2008). In 2007, four companies (Monsanto, DuPont, Syngenta and Groupe Limagrain) controlled more than half of the global proprietary seed market (ETC Group, 2008). And all of them except Limagrain are currently part of prospective mergers or buy-outs that would further increase consolidation throughout the agricultural input chain (Purdy, 2016). Howard (2016) in fact states that "the seed industry is... nearing domination by just two firms".

Many have expressed various concerns that such extreme concentration in this field has drawbacks for both food consumers and producers, depressing innovation and effectively allowing the industry to operate as an oligopolistic trust (Howard, 2016; Moss, 2013; Moss $\&$ Taylor, 2014). Such a high level of concentration also creates a paradox of collaboration. That is, cross-licensing traits theoretically makes IPP less exclusive. However, since the small number of large seed companies often only cross license with each other, this form of "collaboration" may threaten potential for innovation by reducing competition within this group and reinforcing the concentration of power in the industry (Howard, 2016; Moss, 2013). Indeed, in the case of germplasm, unlike other public goods, a depletion in current and future availability can be more related to a lack of use rather than overuse (Montenegro de Wit, 2015). In this way, the feedback between industry consolidation and the use restrictions represented by IPPs in germplasm should be worrisome.

\section{Massively parallel computing? Peasant seed innovations vs. high technology centralization}

As we have presented, contemporary global IPR has been tied to increased consolidation in germplasm research and commercialization, effectively centralizing a huge amount of resources for germplasm "innovation". The centralizing tendencies of global IPR compared to various forms of decentralized breeding have different potential strengths. Centralization often offers greater precision in measuring results, but typically does so by eliminating environmental variance from its considerations, encouraging homogenization and limiting the actual applicability of its innovations to the large diversity of agricultural systems (Desclaux et al., 2012; Howard, 2016). In contrast, decentralized selection may allow greater farmer participation and allow breeding efforts to provide closer matches between innovations and diverse local conditions. Several lines of research have suggested that this may be the case (Aistara, 2011; Desclaux et al., 2012). Decentralized in situ breeding further potentially allows crops to be exposed to their wild relatives, and thereby may incorporate diverse genetic material into the breeding pool (Jarvis \& Hodgkin, 1999). While global IPR may in theory be compatible with this kind of in situ and decentralized efferts, in practice the very basis for these dynamics are restricted under dominant IPPs.

Another line of reasoning to prefer decentralized approaches reiterates Scott's (1998) classic observations on how centralizing forces often necessarily seek to reduce or marginalize vital complexities that otherwise allow local communities to function, innovate, or thrive. The idea that improved innovation and problem-solving may come from allowing great access and freedom to use genetic resources for many decentralized actors is also analogous to the rationales and results from Massively Parallel Computing (e.g., Barney, 2016) and crowdsourcing (e.g., Brabham, 2008). Although these systems are not perfectly analogous, a baseline idea may still apply: that many different centers of experimentation and knowledge may solve problems more quickly than concentrating resources among a smaller number of specialists. And alternative approaches, like Participatory Plant Breeding, represent the potential to combine strengths of decentralization and expert knowledge (Desclaux et al., 2012).

Further, decentralized approaches may be better equipped to deal with the complex relationship between the diversity of cultural practices, crop biodiversity, and the diversity of localized and alternative IPPs (Forsyth, 2016). Stability and distinctiveness requirements of current IPPs, as well as their emphasis on genetic factors above all else can pose obstacles to management strategies that produce valuable and adaptable, but "unstable", cultivars. IPPs may also contribute to systematic failures in acknowledging, recognizing, and respecting the importance of cultural and social practices around seeds, including the meaningful patterns of association between cultural diversity and biodiversity generated by localized factors (Desclaux et al., 2012; Montenegro de Wit, 2015).

Practically speaking, decentralized selection can occur in both formal and informal settings. If done well, formal participatory approaches can balance centralized organization and decentralized selection, and can be more efficient (considering response to selection, adoption by farmers, and cost-benefit ratio) than conventional plant breeding programs (Ceccarelli, 2015). Informal farmer breeding systems take a variety of forms, including highly collaborative community-scale efforts. For example, some informal community breeding projects have involved a small number of farmers interested in performing earlier stage breeding work, with many farmers later selecting from advanced lines and providing the land necessary to grow them (Salazar et al., 2007). 
Bodies of theory on networks and innovation also suggest possible disadvantages to centralized systems (and thus, the current global IPR and concomitant increases in consolidation). Insofar as centralized systems represent increased connectivity between potential "nodes" of innovation or adaptation, they may resemble studies of connected populations and networks in economics and ecology. Findings in both of these fields reflect increased risks of systematic failures and large-scale collapse at high levels of connectivity (Erola et al., 2012; He \& Deem, 2010; Noble et al., 2015; Sensoy et al., 2013). Further, the significant power inequalities represented by centralized, consolidated systems may be directly inimical to innovation, if recent research is to be believed (Farrell \& Shalizi, 2015; Page \& Vandermeer, 2013).

The challenges and potential threats posed by the centralizing nature and unequal power relations present in many projects featuring public funding or international collaboration bear continued scrutiny. Minimizing or even eliminating the current global IPR may be necessary to allow for the most productive forms of decentralization, which might be better-suited to develop effective localized solutions in this realm. At the same time, even a radical revamping of global IPR may be insufficient to challenge centralizing and anti-egalitarian practices and structures, many of which operate on the assumption that centralization will result in desirable and worthwhile efficiency (Brooks, 2011).

\section{Alternative innovation systems}

Numerous proposals exist for alternative innovation systems for plant breeding and that may respond to some of the drawbacks of contemporary global IPR. Proposals range from those that modestly strengthen the public sector within the current regime to those that involve more fundamental dismantling of current IPPs for plant genetic resources. A few suggestions are outlined and discussed here.

Some authors have argued that IPPs, even with recommended improvements to their implementation, should be thought of as only one piece of a larger innovation system (Henry \& Stiglitz, 2010). However, one might step back even further and question, as others have done, the value of emphasizing the idea of "innovation" itself (Russell \& Vinsel, 2016; Van den Hove et al., 2012). In considering innovation to be the ends, we risk overshadowing the importance of maintenance and building work that is not considered inventive, and we also might lose sight of the actual ends that the innovation process is meant to achieve. Thus, we may even consider innovation to be one part of a larger germplasm management system, rather than the point of it, and increase the recognition of the importance of conservation and seed saving activities that might not be considered "innovative".

Even within the "innovation" frame, Henry \& Stiglitz (2010) advocate strengthening mechanisms to reduce the ex post inefficiency created by the knowledge enclosures of dominant IPPs. For example, a liability approach, where anyone can access a given previous innovation for a fixed cost, and patents that are not "winner-take-all" could enable greater follow-on innovation. Incentivizing research with prizes for achieving specific goals, and increasing the amount of research provided through universities could similarly help keep outcomes of high-cost breeding research publicly available (Henry \& Stiglitz, 2010). These authors also explore the complex factors that have motivated people to contribute to highly successful open source software projects, suggesting that a similar structure could be effective in other areas, such as plant breeding.

However, given the properties of plant germplasm; the possible advantages of a decentralized approach; and that it can be considered a "commons" in many ways (Luby \& Goldman, 2016), one place to look for ideas on how to maintain or enhance it and its public use is the voluminous work on common property resource (CPR) management. The diversity of existing and traditional approaches to governing breeding and plant genetic resources in fact bears some similarity to the diversity of formal and informal approaches to governing CPRs, which were notably examined by Ostrom (1990). With reference to sustainably managing CPRs, Ostrom noted that "the centralizers and the privatizers" often advocated oversimplified solutions based on idealized notions of their own effectiveness. The models justifying their authority (e.g., the "tragedy of the commons") often relied on what Ostrom called "extreme assumptions", which could not be properly applied to smaller-scale CPRs. In contrast, as the official website of the Nobel Prize summarized the work for which she was awarded a Nobel, "in many, but not all, cases, allowing users to develop their own rules to regulate the use of common property results in the most efficient solution for managing those resources" (Nobel Media AB, 2014). Whether this general finding applies specifically to the seed/ germplasm commons is an open question. But its possible applicability does, prima facie, further imply a shifting of the burden of proof onto those claiming overall benefits from global IPR.

To this point, one specific alternative approach to the dominant IPR has been developing in the form of the Open Source Seed Initiative (OSSI). OSSI has attempted to create the foundation for a robust, protected commons for plant genetic resources. As OSSI has pursued an approach focused on personal commitments made by the communities breeding and using OSSI-pledged materials, it has embraced a "moral economy" as opposed to a formal and definitively legally enforceable regime (CSA, 2014). OSSI is not currently attempting to coordinate with governments, and in this way the organization has perhaps had more freedom to directly contest the dominant IPR than those operating within that context. And while a "moral economy" approach may seem outdated from the perspective of the nearly-hegemonic Western-style global IPR, the literature on CPRs show that "informal" (i.e., non-state) institutions can be a powerful tool for managing a commons. Thus OSSI's approach has come to focus on the "OSSI Pledge": an agreement that can be printed on seed packets wherein by opening the packet, the opener agrees to not restrict others' use of the germplasm or its derivatives, and to reprint the agreement on seed packets of all future derivatives of the seeds as well (Open Source Seed Initiative, 2016). The protection of derivatives as unpatentable is a critical distinction between this approach and regulations, such as the ITPGR, that do not prevent such privatization and future enclosure of parts of the commons. The open source pledge also decentralizes the very act of participating in the protected commons (or opting out of intellectual property). Agreement and responsibility are relocated to the level of 
individuals transferring the seed packet and enforcement through community norms and building relationships of trust.

Kloppenburg (2010) and CSA (2014) discuss the potential for opensource approaches, like the OSSI pledge, to create more inclusive plant breeding communities, and also to democratize the use of the tools of plant breeding, such as genomic and transgenic techniques. At the same time, given the concerns about OSSI expressed by some farmers and researchers involved in the food sovereignty and agroecology movements, as well as Native American communities (Breen, 2014), it is apparent that there is still work to be done to foster networks and relationships that fully serve all those who are managing biodiversity and agroecosystems, and that may truly serve as an alternative to global IPR.

It also may be possible for an open-source protected commons to coexist with IPP for germplasm, as some plant breeders participating in OSSI have considered releasing certain varieties through the open source system and protecting others under IP (Miller, 2014). However, a thorough exploration of the implications of having a dual commons-IP system is necessary to determine if it would actually be able to provide the potential benefits of both types of systems. At first glance, it seems that doing so would effectively create two separate breeding pools, which may be undesirable. It also seems that it would be difficult to allow patenting traits or specific sequences when such material may also exist in protectedcommons varieties, and there is the distinct possibility that breeders of certain high-quality materials may choose the dominant IPR over a protected commons. Thus, while it may be theoretically feasible for the two to co-exist, it may be that to be successful, a protected commons for plant genetic resources would eventually necessitate the end of the current system of IPPs. A significant possibility, and the one that we have tried to show that there is at least a prima facie argument for, is that this might not be a bad thing for innovation, or society in general.

\section{Conclusions}

At this point, many questions remain around what a more effective germplasm management system might look like. Some researchers have identified the need for future research to apply scenarios and modeling methods to the study of seed networks (Pautasso et al., 2012). Perhaps these methods could also be used to project some of the outcomes of potential changes mentioned above, though as we have pointed out, at least some established economic models have already implied a more open-source/protected-commons IP system may actually help innovation.

That said, one lingering issue is whether any single IPR can effectively support innovations across all contexts, particularly with across so-called "developed" and "developing" countries (Forsyth \& Farran, 2013; Stiglitz, 2014). Similarly, there is room to debate how responsibilities for managing plant genetic resources might be organized with regard to various organizations and scales of government. As Merson (2000) has pointed out, tension may arise when efforts to offer protection for genetic resources in developing countries focus on implementing sovereignty over resources at the national level, while management of plant breeding and biodiversity may actually be occurring on smaller community scales.
Although the food sovereignty movement is concerned with many different issues within contemporary agrifood systems, certain challenges to seed sovereignty could potentially be made moot if a protected commons approach to plant genetic resources were to be the norm. Yet even then, questions would remain with regards to how entities at various scales might bear and exercise responsibilities to support plant breeding and conservation. Most likely, innovation systems that will be able to effectively support a more decentralized, diverse mix of approaches to developing localized plant varieties will need to be compatible with a wide range of governance structures as well. In other words, different geographies, ecosystems, and histories may mean that plant genetic resources are best managed by different sizes and types of organizations from one community to the next, and which acknowledge the many different types of existing intellectual property relations and (still-evolving) traditions (Forsyth, 2016).

As global IPR is currently only becoming more entrenched, the most important step may not be to settle on which new approach might be best, but rather to call into question the appropriateness of a global IPR for plant genetic materials. Given the analysis we have presented, the possibility that the dominant system may well be failing to live up to its purpose, and indeed may be mitigating against its supposedly desired effect, must be seriously considered.

The failings of this system should not surprise us, although the vast majority of those working within the pressures of this regime are likely doing their best to develop socially useful plant varieties within current norms. However, the logic of global IPR assumes that the viability of plant breeding depends first and foremost on its ability to generate profit; such an attitude may be sadly unsurprising to those familiar with the steady history of sublimating food security to other goals (McKeon, 2015). This observation in fact aligns with the pattern wherein societies that see plant breeding as a predominately economic and trade asset tend to implement IPPs, while those prioritizing breeding's value to livelihoods and food security favor more open access systems (Forsyth \& Farran, 2013). Or as Henry \& Stiglitz (2010) have said, "the presumption that profit-maximizing behavior is socially optimal is not always right" (p. 238). However, OSSI Executive Director Claire Luby has asked, "In a globalized system where multinational companies are the major drivers, do societies still get a choice?" If it were to be agreed that alternatives should be more seriously pursued, it would also be incumbent on those who truly wish to support socially-beneficial innovation to agitate within their societies and to their governments to make sure such choices are possible-particularly those of us living in geopolitically powerful countries (like the U.S.) who have strongly influenced global IPR.

In part, what's needed now is to reassess what is seen as success in a management system for plant breeding. For example, we may instead choose to focus on its ability to support a wide range of actors and activities for stable management of biodiversity on many scales. We may consider that a working plant breeding system will necessarily facilitate widespread access, exchange, and use of seeds, support decentralized efforts for local adaptation, and justly recognize the work of farmer-breeders today and over millennia. 
Therefore we must begin instead from these goals, and then ask what regulations or structures might encourage the dedication of the resources that will be necessary to support them, rather than assuming the status quo is the best system. Although any large-scale transition towards alternatives poses serious challenges, this is true of any attempt to fulfil the grand challenges of sustainable, food secure, and resilient agrifood systems. As many in the movements for food sovereignty and agroecology have proposed, working to improve participation, autonomy, political agency, and especially power imbalances will be indispensable in any attempt to prioritize these values and foster a more just and sustainable world (Chappell et al., 2013; Farrell \& Shalizi, 2015; Perfecto et al., 2009).

\section{Author contributions}

Each author contributed equally to the final product. MJC conceived the paper. Research, writing, and revision were carried out by $\mathrm{MH}$ and MJC.
Competing interests

MJC sits on the Board of Directors of the Open Source Seed Initiative (OSSI). At the time of the conception and initial drafting of this paper, MJC and MH both worked for the Institute for Agriculture and Trade Policy (IATP). IATP helped found OSSI and is a partner organization. The work here reflects the analysis performed by $\mathrm{MH}$ and MJC, and does not necessarily reflect the views of OSSI or IATP.

\section{Grant information}

The author(s) declared that no grants were involved in supporting this work.

\section{Acknowledgments}

We gratefully acknowledge help from a number of sources, including support for MH's participation from the Institute of Agriculture and Trade Policy and Chatham University; and feedback on earlier drafts from C. Luby, J. Loos, J. Taylor and F. Shaw.
Aistara G: Seeds of kin, kin of seeds: The commodification of organic seeds and social relations in Costa Rica and Latvia. Ethnography. 2011; 12(4): 490-517.

Publisher Full Text

Akerlof GA: The market for "lemons": Quality uncertainty and the market mechanism. Q J Econ. 1970; 84(3): 488-500.

Publisher Full Text

Aoki K: "Free seeds, not free beer": participatory plant breeding, open source seeds, and acknowledging user innovation in agriculture. Fordham Law Rev. 2009; 77(5): 2275.

Reference Source

Barney B: Introduction to Parallel Computing. Livermore, CA: Lawrence Livermore National Laboratory, 2016.

Reference Source

Beddington J: Food security: contributions from science to a new and greener revolution. Philos Trans R Soc Lond B Biol Sci. 2010; 365(1537): 61-71. PubMed Abstract | Publisher Full Text | Free Full Text

Brabham DC: Crowdsourcing as a Model for Problem Solving: An Introduction and Cases. Convergence. 2008; 14(1): 75-90.

Publisher Full Text

Breen SD: Saving seeds: The Svalbard Global Seed Vault, Native American seed savers, and problems of property. J Agric Food Syst Community Dev. 2014; 5(2): 39

Publisher Full Text

Brooks S: Is international agricultural research a global public good? The case of rice biofortification. J Peasant Stud. 2011; 38(1): 67-80.

PubMed Abstract | Publisher Full Text

Bulte E, Beekman G, Di Falco S, et al.: Behavioral Responses and the Impact

of New Agricultural Technologies: Evidence from a Double-blind Field

Experiment in Tanzania. Am J Agr Econ. 2014; 96(3): 813-830.

Publisher Full Text

Butruille DV, Birru FH, Boerboom ML, et al:: Maize Breeding in the United States: Views from Within Monsanto. In J. Janick (Ed.), Plant Breeding Reviews. John Wiley \& Sons, Inc. 2015; 39: 199-282.

Publisher Full Text

Ceccarelli S: Efficiency of plant breeding. Crop Sci. 2015; 55(1): 87-97.

Publisher Full Text

Centre for Sustainable Agriculture (CSA): Building open source seed: Agriculture and Biodiversity Community 2014. Secunderabad, India: Centre for Sustainable Agriculture, 2014.

Reference Source

Chappell MJ, Wittman H, Bacon CM, et al.: Food sovereignty: an alternative paradigm for poverty reduction and biodiversity conservation in Latin America [version 1; referees: 2 approved]. F1000Res. 2013; 2: 235.

PubMed Abstract | Publisher Full Text | Free Full Text

Cimoli M, Dosi G, Maskus KE, et al.: The role of intellectual property rights in developing countries: Some conclusions. In M. Cimoli, G. Dosi, K. E. Maskus,
R. L. Okediji, and J. H. Reichman (Eds.), Intellectual property rights: Legal and economic challenges for development. Oxford University Press: Oxford. 2014; 503-513.

Publisher Full Text

Desclaux D, Ceccarelli S, Navazio J, et al.: Centralized or decentralized breeding: the potential of participatory approaches for low-input and organic agriculture. Organic Crop Breeding. Wiley-Blackwell: Hoboken. 2012; 99-123. Publisher Full Text

Elkin-Koren N: What contracts cannot do: The limits of private ordering in facilitating a creative commons. Fordham Law Review. 2005; 74(2): 375-422. Reference Source

Erola P, Díaz-Guilera A, Gómez S, et al.: Modeling international crisis synchronization in the world trade web. Networks \& Heterogeneous Media. 2012 7(3): 385-397.

Publisher Full Text

ETC Group: Who Owns Nature? Corporate Power and the Final Frontier in the Commodification of Life. Ottawa: ETC Group, 2008.

Reference Source

Farrell H, Shalizi CR: Pursuing Cognitive Democracy. In D. Allen \& J. Light (Eds.), From Voice to Influence: Understanding citizenship in a digital age. Chicago: The University of Chicago Press. 2015.

Reference Source

Forsyth M, Farran S: Intellectual Property and Food Security in Least Developed Countries. Third World Q. 2013; 34(3): 516-533. Publisher Full Text

Forsyth M: Making the case for a pluralistic approach to intellectual property regulation in developing countries. Queen Mary J Intell Proper. 2016; 6(1): 3-26.

Publisher Full Text

Goodman MM: New sources of germplasm: Lines, transgenes, and breeders. In J. M. Martinez R., F. Rincon S., G. Martinez G. (Eds.), Memoria Congresso Nacional do Fitogenetica. Saltillo, COAH, Mexico: Universidad Autónoma Agraria Antonio Narro. 2002; 28-41.

Reference Source

Harhoff D, Régibeau P, Rockett K: Some simple economics of GM food. Econ Policy. 2001; 16(33): 264-299.

Publisher Full Text

$\mathrm{He}$ J, Deem MW: Structure and response in the world trade network. Phys Rev Lett. 2010; 105(19): 198701

Publisher Full Text

Heald P, Chapman S: Veggie Tales: Pernicious Myths About Patents, Innovation, And Crop Diversity In The Twentieth Century. Illinois Public Law Research Paper No. 11-03. 2011.

Publisher Full Text

Heller MA, Eisenberg RS: Can patents deter innovation? The anticommons in biomedical research. Science. 1998; 280(5364): 698-701.

PubMed Abstract | Publisher Full Text 
Henry C, Stiglitz JE: Intellectual Property, Dissemination of Innovation and Sustainable Development. Glob Policy. 2010; 1(3): 237-251.

Publisher Full Text

Howard P: Concentration and power in the food System: Who controls what we eat? London: Bloomsbury, 2016.

Reference Source

International Assessment of Agricultural Knowledge Science and Technology for Development (IAASTD): Agriculture at a crossroads: International assessment of agricultural knowledge, science and technology for development. Washington, D.C.: Island Press, 2009.

Reference Source

Jarvis $\mathrm{D}$, Hodgkin $\mathrm{T}$ : Wild relatives and crop cultivars: detecting natural introgression and farmer selection of new genetic combinations in agroecosystems. Mol Ecol. 1999; 8(s1): 159-173.

Publisher Full Text

Joubert P: Business as usual is dead: how businesses are transcending boundaries to fight climate change. OlamGroup.com. 2016.

Reference Source

Kloppenburg J: First the seed: The political economy of plant biotechnology.

(2nd ed.). Madison, WI: University of Wisconsin Press, 2004.

Reference Source

Kloppenburg J: Impeding Dispossession, Enabling Repossession: Biological Open Source and the Recovery of Seed Sovereignty. Journal Of Agrarian

Change. 2010; (3): 367-388.

Publisher Full Text

Kloppenburg J: Re-purposing the master's tools: the open source seed initiative and the struggle for seed sovereignty. J Peasant Stud. 2014; 41(6): 1225-1246.

Publisher Full Text

Lappé FM, Collins J: World hunger: Ten myths. New York: Grove Press/Food First Books, 2015.

Reference Source

Loevinsohn M, Sumberg J, Diagne A, et al: Under what circumstances and conditions does adoption of technology result in increased agricultural productivity? A Systematic Review prepared for the Department for International Development. Brighton, UK: IDS, 2013

Reference Source

Luby $\mathrm{CH}$, Goldman IL: Freeing Crop Genetics through the Open Source Seed Initiative. PLOS Biol. 2016; 14(4): e1002441.

Initiative. PLOS Biol. 2016; 14(4): e1002441.
PubMed Abstract | Publisher Full Text | Free Full Text

Marco AC, Rausser GC: The Role of Patent Rights in Mergers: Consolidation in Plant Biotechnology. Am J Agric Econ. 2008; 90(1): 133-151.

Publisher Full Text

McKeon N: Food Security Governance: Empowering Communities, Regulating Corporations. Routledge, 2015.

Reference Source

Merson J: Bio-prospecting or bio-piracy: intellectual property rights and biodiversity in a colonial and postcolonial context. Osiris. 2000; 15 282-296.

PubMed Abstract | Publisher Full Tex

Miller N: Novel open source seed pledge aims to keep new vegetable and grain varieties free for all. University of Wisconsin News. 2014.

Reference Source

Monsanto: Why does agriculture need to be improved? Monsanto.com. 2002-2015.

Reference Source

Montenegro de Wit M: Are we losing diversity? Navigating ecological, political, and epistemic dimensions of agrobiodiversity conservation. Agric Human Values. 2015; 33(3): 625-640.

Publisher Full Tex

Moschini G: Competition issues in the seed industry and the role of intellectual property. Choices. The Magazine of Food, Farm, And Resources Issues. 2010; 25(2)

Reference Source

Moss DL: Competition, intellectual property rights, and transgenic seed. $S D$ Law Rev. 2013; 58: 543.

Reference Source

Moss DL, Taylor CR: Short Ends of the Stick: The Plight of Growers and Consumers in Concentrated Agricultural Supply Chains. Wis L Rev 2014; 2014(2): 337-368.

Reference Source

Nobel Media AB: The Prize in Economics 2009 - Speed Read. NobelPrize.org.
2014

Reference Source

Noble AE, Machta J, Hastings A: Emergent long-range synchronization of oscillating ecological populations without external forcing described by Ising universality. Nat Commun. 2015; 66664

PubMed Abstract | Publisher Full Text | Free Full Tex

Open Source Seed Initiative: About. OSSeeds.org. 2016.

Reference Source

Ostrom E: Governing the commons: The Evolution of Institutions for Collective Action. New York: Cambridge University Press. 1990.

Reference Sourc

Page SE, Vandermeer J: Inequality and innovativeness. Econ Bull. 2013; 33(1):

Reference Source

Pardey $\mathrm{P}, \mathrm{Koo} \mathrm{B}$, Drew J, et al:: The evolving landscape of plant varietal rights in the United States, 1930-2008. Nat Biotechnol. 2013; 31(1): 25-29.

PubMed Abstract | Publisher Full Text | Free Full Text

Pautasso M, Aistara G, Barnaud A, et al: Seed exchange networks for agrobiodiversity conservation. A review. Agron Sustain Dev. 2012; 33(1):

$151-175$

Publisher Full Text

Perfecto I, Vandermeer JH, Wright AL: Nature's matrix: Linking agriculture, conservation and food sovereignty. London: Earthscan. 2009.

Reference Source

Purdy C: Six companies are about to merge into the biggest farm-business oligopoly in history. Quartz.com. 2016.

Reference Source

Russell A, Vinsel L: Hail the maintainers. Aeon. 2016.

Reference Source

Salazar R, Louwaars NP, Visser B: Protecting Farmers' New Varieties: New Approaches to Rights on Collective Innovations in Plant Genetic Resources. World Dev. 2007; 35(9): 1515-1528.

Publisher Full Text

Scalise DG, Nugent D: International intellectual property protections for living matter: biotechnology, multinational conventions and the exception for agriculture. Case West Reserve J Int Law. 1995; 27(1): 83

Reference Source

Scott JC: Seeing like a state: How certain schemes to improve the human condition have failed. Yale University Press. 1998.

Reference Source

Sensoy A, Yuksel S, Erturk M: Analysis of cross-correlations between financial markets after the $\mathbf{2 0 0 8}$ crisis. Physica A: Statistical Mechanics and its Applications. 2013; 392(20): 5027-5045.

Publisher Full Text

Stiglitz JE: Intellectual property rights, the pool of knowledge, and innovation NBER Working Paper No. 20014. 2014.

Reference Source

Stone GD, Flachs A, Diepenbrock C: Rhythms of the herd: Long term dynamics in seed choice by Indian farmers. Technol Soc. 2014; 36: 26-38.

Publisher Full Text

Unilever: The Unilever Sustainable Living Plan: Our strategy for sustainable business. Unilever.com. 2016 .

Reference Source

van den Hove S, McGlade J, Mottet $P$, et al: The Innovation Union: a perfect means to confused ends? Environ Sci Policy. 2012; 16: 73-80.

Publisher Full Text

van Dooren T: Inventing seed: The nature(s) of intellectual property in plants. Environ Plann D. 2008; 26(4): 676-697.

Publisher Full Text

Vanloqueren G, Baret PV: How agricultural research systems shape a technological regime that develops genetic engineering but locks out agroecological innovations. Res Policy. 2009; 38(6): 971-983.

Publisher Full Text

Vogel JH, Álvarez-Berríos N, Quiñones-Vilches N, et al.: The economics of information, studiously ignored in the Nagoya Protocol on Access to Genetic Resources and Benefit Sharing. Law, Environment and Development Journal. $2011 ; 7(1): 52$

Reference Source

vom Brocke K, Christinck A, Weltzien RE, et al.: Farmers' seed systems and management practices determine pearl millet genetic diversity patterns in semiarid regions of India. Crop Sci. 2003; 43(5): 1680-1689.

Publisher Full Text 


\section{Open Peer Review}

\section{Current Peer Review Status:}

\section{Version 1}

Reviewer Report 12 July 2017

https://doi.org/10.5256/f1000research.11312.r21085

(C) 2017 Aistara G et al. This is an open access peer review report distributed under the terms of the Creative Commons Attribution License, which permits unrestricted use, distribution, and reproduction in any medium, provided the original work is properly cited.

\section{Guntra A. Aistara}

Department of Environmental Sciences and Policy, Central European University, Budapest, Hungary

\section{Ana Ruth Martinez Rizo}

Department of Environmental Sciences and Policy, Central European University, Budapest, Hungary

In this opinion essay, the co-authors Halpert and Chappell question whether conventional intellectual property protections (IPPs) for germplasm contribute to or limit socially beneficial innovation in the face of today's large-scale agricultural challenges of simultaneously achieving food security and environmental sustainability. They present a clear argument, supporting their opinion with relevant literature.

The essay is excellent and the conclusions are balanced and justified based on the evidence and arguments presented. Nevertheless, the topics covered raise a few further observations on the history of these debates that continue to create obstacles for alternative IP regimes, the exploration of which would help contextualize the current paper and hoped for solutions. These revolve around the definition of the "common heritage of mankind;" the separation of breeders from farmers; and the breeders' and farmers' exceptions present in UPOV-related regimes as opposed to patents. These debates have undergirded discussions about access to and sharing of benefits from agrobiodiversity, and may continue to pose obstacles for the types of alternatives suggested by the authors, necessary for fostering a more "just and sustainable world" (p. 9).

The authors summarize the US 1930 Plant Patent Act (PPA), the Plant Variety Protection (PVP) certificates in force since the 1970s, and the 1980 Diamond vs. Chakrabarty US Supreme Court case, which allowed utility patents to be used for plant varieties. These IPPs may also be combined in "dual protection" systems, or reinforced and spread through international treaties such as the Union for Plant Variety Protection (UPOV) and the World Trade Organization Trade Related Intellectual Property Rights (TRIPS) agreement. One exception to more restrictive IPPs is the FAO International Treaty on Plant Genetic Resources (ITPGR), which limits the opportunity to obtain patents on genetic materials received from international gene banks, though it does not prevent 
the patenting of genetic materials subsequently derived from those materials.

Halpert and Chappell review critiques and evidence that IPPs may be taking more from the knowledge pool than they are giving back, in effect creating an "anti-commons" (citing Heller \& Eisenberg 1998). They argue that IPPs should encourage further research to create more diversity, and cite studies showing that sometimes the opposite is true, therefore indicating a weak, or even inverse relationship between IPPs and innovation in plant breeding. The authors refer to the inability of farmers to quickly distinguish the benefits of one seed versus another, and emphasize how difficult it is to evaluate the benefits of the supposed innovation in plant breeding, a fact that in the end can benefit IPP holders at the expense of farmers. The authors then explain how the fact that a few companies now control the global seed industry negatively affects genetic diversity and is facilitated by the IPPs.

Finally, Halpert and Chappell analyze the centralizing tendencies of IPPs and compare them to decentralized breeding schemes, showing evidence of the benefits of decentralized in situ management strategies. The authors introduce alternative innovation systems, such as the Open Source Seed Initiative (OSSI). OSSI functions through a "pledge" printed on seed packets, whereby users agree not to restrict anyone else's use of the germplasm or future derivatives of it. While this alternative of creating a "protected commons" offers individuals a way to opt out of dominant intellectual property regimes, the authors submit that an exploration of the implications of the coexistence of open source and dominant IPPs will be necessary in order to evaluate the longterm effects on plant breeding and access to seeds.

The authors conclude that even if there are still a lot of questions to be answered about alternative open source/protected commons intellectual property regimes, it is necessary to question the assumption that dominant IP regimes are the only option that encourage innovation, and may in fact deter it, proposing that we may need to rethink what we mean by success in plant breeding.

\section{Common heritage versus common concern}

The authors frame their inquiry in terms of "socially beneficial innovations," but this raises a question about who defines the public good and how? The authors note that "some agreements have attempted to regulate plant genetic resources as common heritage" (p. 4), citing the ITPGR as an example. It is important to note, however, that even the ITPGR is not framed as "common heritage", and it was exactly debates over whether or not plant genetic resources are a part of the "common heritage" of humankind that began the slow slide from a global commons approach to the dominant IPP approach. The concept of "common heritage" does not have one agreed definition, but was nevertheless diluted to an unspecified "heritage of mankind" in the ITPGR and a "common concern of humankind" in the CBD, because there has been no agreement on this issue since negotiations began on the FAO International Undertaking on Plant Genetic Resources in the 1980 s (Brush $2007^{1}$, Murillo 2008²). This history of disagreement will also make a 'return' to a protected commons approach more difficult.

This is also significant because if the heritage of genetic resources is not seen as "common," it is necessary to separate out groups who are the true "heirs" of these resources, and thus considered more suited to act on behalf of the "common concern of humankind" than others. These groups will thus be granted privileged access to the resources, or rights to further develop 
them. Although the ITPGR "recognizes the enormous contribution farmers have made to the ongoing development of the world's wealth of plant genetic resources," the farmers' rights protections in the treaty have never had the same legal standing as IPPs, which enforce breeders' rights to develop and protect varieties. This has created a separation of farmers from breeders, and established breeders in effect as the rightful heirs and developers of genetic resources.

\section{Farmers versus breeders}

The authors rightly point out that due to the broad range of cultural and environmental factors that affect plant breeding and growing practices, "it would seem appropriate to have an innovation system that encourages greater accessibility to knowledge for a diversity of approaches and actors" (p. 4). This would presume, however, that all of these different knowledge systems are equally valued, which has not been the case at least since the beginning of the dominant IP regime development, which has consciously enforced a separation between farmers and breeders and their knowledge systems.

All new plant varieties protected under IPPs have been created using genetic materials that are a co-product of natural selection and farmer selection. Van Dooren (2008) $)^{3}$ provides an insightful analysis of how foregrounding the "invention" of seeds or varieties by breeders, over the intricate webs of farmer and non-human interactions that have come before them, and on which they depend, results in fetishism of the seed. He observes that this creates a division between breeders as true "inventors" who are representative of "culture," versus farmers who remain trapped as a part of "nature." This also prioritizes the investments of individuals or institutions in the present and future over historical ones (Aistara 20124).

This separation of farmers from breeders forces a separation of scientific knowledge from traditional knowledge and creates scientific experts who are seen as better able to manage important global concerns. The UPOV system was originally differentiated from patents, in that discoveries of natural genetic mutation or cross- pollination, often made by farmers, could also be protected, which was not possible under patent law. Subsequently the UPOV treaty was also changed to require "discovery and development" rather than just discovery (UPOV $2002^{5}$ ), narrowing the interpretation of breeding to fit laboratory settings more readily than farmers (Aistara 2012 ${ }^{4}$ ). This separation becomes especially important once different "exceptions" are applied to the different groups.

\section{Exceptions versus exclusions}

As the authors note, "Unlike PVPs, the extension of utility patenting to plant and genetic materials involved no exceptions for seed saving, research, or other breeding activities" (p. 3). Indeed one of the main differences between patents and the UPOV regime and PVPs is that UPOV includes both a breeders' exception and a farmers' exception. There are fundamental inequalities between these exceptions, however. While the breeders' exception allows breeders public access to protected germplasm for research purposes and the development of new varieties, the farmers' exception, since the 1991 revision of UPOV, allows farmers to replant varieties for consumption purposes only. With the increasing narrowing of the farmers' exception, similarities between UPOV and patents increase. Even in cases where the farmers' exception does apply, it is sometimes so narrowly economically defined that it excludes income-generating farmers (Aistara 20124). More importantly, the farmers' exception does not allow a space for farmer breeding using protected varieties. What is specifically allowed by exception for some (breeders) becomes a criminal act for others (farmers) (ibid). 
The different functions of the exceptions are indicative of how dominant IPPs define innovation. The breeders' exception is meant to allow for innovation, while the farmers' exception is only meant to allow for consumption. If farmers are seen as consumers, rather than also potential breeders, they are effectively excluded from the possibility of innovation, despite the fact that is was farmer innovation over generations that created the diversity of varieties upon which breeders now depend. By separating the act of farming from breeding, it also separates the intangible versus tangible aspects of knowledge that surround farmer breeding, and that have been passed down with seeds over generations (Aistara forthcoming ${ }^{6}$ ). Losing this knowledge by constricting the space for farmer breeding practices may hinder future innovation.

The future-oriented idea of innovation also excludes many of the reasons why farmers' may have innovated, and thus bred diversity, in the first place. There are benefits and uses from farmer-bred varieties that reach much beyond yield, and these other values and uses of seeds are also excluded from innovation in the future, because farmers do still tend to cross their own varieties with protected varieties, as noted by the authors (citing Salazar 2007). The farmers' exception thus functions more as exclusion. Furthermore, farmer breeding is tightly interwoven with farmer seed exchange practices and social networks, which may have been what gave the diversity of seeds meaning in the first place, and may thus be the inspiration for innovation (Aistara $2011^{7}$ ). Cutting social networks of exchange through the imposition of IPPs (Strathern $1996^{8}$, Aistara forthcoming $\left.{ }^{6}\right)$ may thus also cut off future innovations.

While patents have been mainly used in the US, UPOV has dominated in Europe and is spreading throughout many developing countries as a requirement of free trade agreements. There has recently been a push to move towards plant patents for conventional breeding techniques in Europe as well, which would eliminate the breeders' exception. Ironically, the European Seed Association, a breeders' trade association, opposed patents for conventional breeding techniques or based on "purely biological processes" (as opposed to biotechnology) for precisely the same reason that farmer-breeders have opposed their own exclusion from the breeders' exception:

“The breeders' exemption is the cornerstone of a system that successfully balances the protection of individual intellectual property with the common interest of society to introduce innovation broadly and quickly by allowing free access for further research and breeding. This decision has the potential to not only restrict this free access to quite a number of products, but also to generally discourage breeding efforts in areas covered by such patents in the future."

The ESA 2012 Position on Intellectual Property Protection for Plant-Related Inventions in Europe even goes on to claim that the breeders' exception “can be regarded as a kind of 'open source' system and has always been relied upon by breeders for further improvement on each other's varieties and boosted innovation in plant breeding." This reinforces the fact that the question is really about who is included or excluded from the definition of breeder and thus has the exclusive rights to derive benefits from improving plant genetic resources that have already been improved upon for over 10,000 years. Dominant IPPs still try to create "privately public access" for some to derive exclusive benefits from such germplasm while excluding others (Aistara 20124), while true open source systems like the OSSI try to both broaden that space of access, and prevent certain groups from deriving unfair benefits at the expense of others from open source germplasm in the future. 


\section{Open Futures?}

As the authors indicate, many questions remain unresolved both about how open source or other alternative innovation systems might work in practice, and how they will co-exist with dominant IPPs. For example, rather than simply "building relationships of trust" (p. 8), how well would the OSSI pledge, still a hybrid between formal and informal systems, work in systems where farmers may lack skills to read and write or be reluctant to enter even into semi-formal agreements? How would the OSSI pledge work for acknowledging innovation at the community rather than individual level, for example in areas such as the Potato Park in Peru, and how does it intersect with current legal norms (Martinez Rizo, forthcoming ${ }^{9}$ )?

Halpert and Chappell suggest that rather than starting from the existing system, we should start from a set of goals and structure the system to accommodate it. Indeed in the meantime the first step would be to reform dominant IP regimes, including exceptions in both patents and UPOV/PVP systems. But rather than maintaining unequal exceptions for particular types of actors, exceptions should be made available for particular types of activities or purposes, such as for the maintenance of diversity, for research and development, for food security purposes, or even for small-scale business development purposes. This would already be a step towards maintaining a more open playing field and ending the segregation of actors and knowledge systems. Each such purpose will require different norms than the current requirements of novelty, distinctness, uniformity and stability, as well as options for recognizing community as well as individual contributions to breeding. OSSI and other open source seed initiatives would then be well placed to further broaden the spectrum of alternative approaches to facilitate both diversity and justice in seed politics.

\section{References}

1. Brush S.B.: The demise of 'common heritage' and protection for traditional agricultural knowledge. Biodiversity and the law: intellectual property, biotechnology and traditional knowledge. 2007. 297-315

2. Murillo J: Common concern of humankind and its implications in international environmental law. Macquarie Journal of International and Comparative Environmental Law. 2008; 5: 113-147 3. van Dooren T: Inventing Seed: The Nature(s) of Intellectual Property in Plants. Environment and Planning D: Society and Space. 2008; 26 (4): 676-697 Publisher Full Text

4. Aistara G: Privately public seeds: competing visions of property, personhood, and democracy in Costa Rica's entry into CAFTA and the Union for Plant Variety Protection (UPOV). Journal of Political Ecology. 2012; 19: 127-144

5. UPOV: The notion of breeder and common knowledge in the plant variety protection system based upon the UPOV convention Geneva. 2002. 8

6. Aistara G: Organic Sovereignties: Struggles over Farming in an Age of Free Trade: In Press. University of Washington Press.

7. Aistara G: Seeds of kin, kin of seeds: The commodification of organic seeds and social relations in Costa Rica and Latvia. Ethnography. 2011; 12 (4): 490-517 Publisher Full Text

8. Strathern M: Cutting the network. Journal of the Royal Anthropological Institute. 1996. 517-535

9. Martinez Rizo A: The implementation of an open source seed approach in Parque de la Papa, Peru: Innovation and knowledge from a community perspective: In Press. Central European University.

\section{Is the topic of the opinion article discussed accurately in the context of the current}




\section{literature? \\ Yes \\ Are all factual statements correct and adequately supported by citations? \\ Yes}

Are arguments sufficiently supported by evidence from the published literature?

Yes

Are the conclusions drawn balanced and justified on the basis of the presented arguments? Yes

Competing Interests: No competing interests were disclosed.

Reviewer Expertise: Environmental anthropology, organic agriculture, agrobiodiversity, intellectual property rights on seeds

We confirm that we have read this submission and believe that we have an appropriate level of expertise to confirm that it is of an acceptable scientific standard.

Reviewer Report 27 April 2017

https://doi.org/10.5256/f1000research.11312.r22291

(C) 2017 Farran S. This is an open access peer review report distributed under the terms of the Creative Commons Attribution License, which permits unrestricted use, distribution, and reproduction in any medium, provided the original work is properly cited.

\section{Sue Farran}

Northumbria Law School, Northumbria University , Newcastle, UK

This is an interesting article which makes a number of robust criticisms of the application of IPR to germplasm and linked to this consequences of food security. It is very wide ranging and treads a sometimes difficult and not always successful path between the global and the local. Indeed while the current global IPR regime is clearly unsatisfactory, and this is a case well made, it is not always clear if the solution also lies at a global or more nuanced local and diffuse level.

For clarity given the potential international readership it should be made clear what aspects and information are USA located and what not.

More use might have been made of literature and examples from Africa and India in respect of food security, IPR and seeds/germplasm. Nevertheless, this article makes an important contribution to the debate on the stranglehold of the current global regime and usefully identifies a number of areas needing further research.

A further strength of the article, which is introduced but not yet fully explored, is drawing from 
other disciplines and theoretical models to challenge the claimed benefits of the current regime.

Is the topic of the opinion article discussed accurately in the context of the current literature?

Yes

Are all factual statements correct and adequately supported by citations?

Yes

Are arguments sufficiently supported by evidence from the published literature? Partly

Are the conclusions drawn balanced and justified on the basis of the presented arguments? Yes

Competing Interests: No competing interests were disclosed.

Reviewer Expertise: Legal pluralism, Pacific legal studies, intellectual property, human rights

I confirm that I have read this submission and believe that I have an appropriate level of expertise to confirm that it is of an acceptable scientific standard.

Reviewer Report 19 April 2017

https://doi.org/10.5256/f1000research.11312.r21368

(C) 2017 Tracy W. This is an open access peer review report distributed under the terms of the Creative Commons Attribution License, which permits unrestricted use, distribution, and reproduction in any medium, provided the original work is properly cited.

\section{William F. Tracy}

Department of Agronomy, University of Wisconsin-Madison, Madison, WI, USA

This is an opinion article on issues surrounding intellectual property regimes. It is well written and easy to read. As an opinion piece it cites previous publications and does not generate new data or knowledge. The main thesis of the article is that intellectual property regimes in cultivated plants are "neither necessary nor sufficient to generate socially beneficial improvements in crop plants and maintain agrobiodiversity". The authors go further and dispute the benefits of IP in spurring innovation and greater gains in plant improvement, a conclusion many would dispute. I am quite open to this argument and the authors do a good job citing literature to support their position. The authors also discuss the negative effects of IP on 'collaborative and cumulative plant breeding', a conclusion with which, I think, most observers would agree. They also blame the use of IP for the decline of pubic plant breeding at universities, NGOs, and International Centers. While IP may have a role in this decline, neoliberal economic policies have been the main culprit. In fact we can locate the rise of IPP in plant breeding on those economic policies. Despite this quibble over the decline in public plant breeding, I tend to agree with, or at least am open to, 
many of the authors arguments.

My main concern with the article is that while they did an extensive literature review of papers that support their point of view, the review of the extensive body of opposing literature is almost nonexistent. The few papers they mentioned are often from companies, which some readers might dismiss out of hand. Many readers, especially those antagonistic to the authors' thesis, will dismiss the current article because it does not address any of the numerous opposing publications and the data they include. I suggest the authors start by reviewing Smith et al., $2016^{1}$ and the literature contained therein. This is a review that comes to a diametrically opposed conclusion from the current paper. It has an extensive citation list supporting their conclusions. I will state here that I do not agree with many of the conclusions and extrapolations in Smith et al. ${ }^{1}$ but it and many other articles opposing the conclusions of the current piece are out there and they need to addressed be the authors for this article to be taken seriously.

Finally, in the authors' promotion of open source proposals, they recognize the concerns of food and seed sovereignty movements, but they do not address the chilling effect of the derivative clause on the widespread use of germplasm developed with public funds. To justify public support of breeding programs the germplasm needs to be made available as widely as possible with freedom to operate. Many public and private breeders will not use open source material because of restrictions on ownership of derivatives.

\section{References}

1. Smith S, Lence S, Hayes D, Alston J, et al.: Elements of Intellectual Property Protection in Plant Breeding and Biotechnology: Interactions and Outcomes. Crop Science. 2016; 56 (4). Publisher Full Text

Is the topic of the opinion article discussed accurately in the context of the current literature?

No

Are all factual statements correct and adequately supported by citations? No

Are arguments sufficiently supported by evidence from the published literature? Yes

Are the conclusions drawn balanced and justified on the basis of the presented arguments? Yes

Competing Interests: No competing interests were disclosed.

Reviewer Expertise: Plant breeding

I confirm that I have read this submission and believe that I have an appropriate level of expertise to confirm that it is of an acceptable scientific standard, however I have significant reservations, as outlined above. 
Reviewer Report 10 April 2017

https://doi.org/10.5256/f1000research.11312.r21078

(C) 2017 Breen S. This is an open access peer review report distributed under the terms of the Creative Commons Attribution License, which permits unrestricted use, distribution, and reproduction in any medium, provided the original work is properly cited.

\section{Sheryl D. Breen}

Political Science Environmental Studies, University of Minnesota Morris, Morris, MN, USA

Halpert and Chappell provide a knowledgeable, well-written overview of global intellectual property protections and plant genetic resources and present a set of arguments for moving toward an alternative open-source approach. As they point out in their introduction, the widespread assumption is that monopoly patents on germplasm can pass a cost-benefit analysis test by creating paths for future innovation. The authors question the truth of this assumption, however, and ask whether alternative approaches such as the open-source framework also can support agricultural innovation while decreasing the ex post inefficiency of the intellectual property regime.

Intellectual property protections for plants in the U.S. and in international agreements: This section describes the evolution of a global intellectual property regime, primarily following the utilitarian approach of the United States and its development of plant patents, Plant Variety Protection (PVP) certificates, and utility patents. The authors provide a brief, useful summary of each stage in this development within U.S. law as well as the parallel international moves toward the International Union for the Protection of New Varieties of Plants (UPOV) and the World Trade Organization's requirements in the Agreement on Trade-Related Aspects of Intellectual Property Rights (TRIPS). While alternatives have been possible, the authors write, they have remained limited within the global intellectual property rights regime.

Draining the pool of knowledge: Enclosing more than giving back: The authors ask whether intellectual property protections in fact erect barriers against future innovation, contrary to the widespread assumption, and thus decrease rather than augment our collective knowledge of agriculture and plant breeding. Using both theoretical arguments and empirical examples, Halpert and Chappell describe the way that plant patents promote the "anti-commons," suppressing potentially valuable avenues of research. They present evidence that raises significant doubts about the validity of claims that plant patents lead to more or better commercial varieties and conclude that intellectual property protections for germplasm have not demonstrated their ability to promote needed innovation, much less net contributions to collective knowledge.

Further considerations challenging contemporary dominant IPR: This section provides further evidence that the global intellectual property regime may harm public goods, including biodiversity. The authors point out that research on agricultural innovation so far has been unsatisfying and that farmers' decision-making on varieties does not provide reliable evidence of seed performance. In contrast, the seed industry has rapidly consolidated and is dominated by a small number of corporations. 
Massively parallel computing? Peasant seed innovations vs. high technology centralization: The authors compare the costs and benefits of centralized systems for plant breeding innovation in the global intellectual property regime and decentralized selection as practiced by peasant farmers. Unlike the centralized system, peasant farmers' in situ practices promote integration with local soil and climate conditions and allow exposure to wild relatives and resulting increases in biodiversity. Drawing from theories of Massively Parallel Computing and crowdsourcing, the authors suggest that decentralized problem-solving is more efficient and can take both formal and informal approaches. In contract, the centralized intellectual property regime is less able to recognize and respond to localized cultural and social practices, is prone to power differences that stifle innovation, and may be at higher risk of large-scale failure.

Alternative innovation systems: So far, the authors have challenged the belief that the global intellectual property regime is necessary and efficient in terms of plant breeding innovation. In this section, they lay out possible alternative systems, including revisions within the plant patent system, the use of common property resource management, a protected commons envisioned by the Open Source Seed Initiative, the establishment of a dual commons-intellectual property system, and - most radically - the elimination of intellectual property protections for plant genetic resources. These alternatives are not explored at length in this section, but the authors present a significant portfolio of possibilities that, in various ways, question the foundational assumptions beneath the intellectual property system and call for innovation in new directions.

Conclusions: The final section brings the authors to two concluding questions: 1) Can a single, centralized system of germplasm management encompass the wide range of traditions, practices, and relationships surrounding plant genetic resources? 2) How do we define "success" in a plant breeding management system? In other words, what are our goals? The authors suggest that multiple approaches are more promising than a unified global system and that the goal of profit maximization is limited and, when monopolistic, harmful.

Overall, this article follows well-recognized standards of argumentation and includes credible, authoritative sources in its review of the literature. Two minor corrections are necessary, both in the conclusion:

1. Page 8, left column, second and third line of final paragraph: either "with" or "across" needs deletion;

2. Page 8, right column, third paragraph: Quotation from Claire Luby is not cited.

Is the topic of the opinion article discussed accurately in the context of the current literature?

Yes

Are all factual statements correct and adequately supported by citations? Yes

Are arguments sufficiently supported by evidence from the published literature? Yes

Are the conclusions drawn balanced and justified on the basis of the presented arguments? 
Yes

Competing Interests: No competing interests were disclosed.

I confirm that I have read this submission and believe that I have an appropriate level of expertise to confirm that it is of an acceptable scientific standard.

The benefits of publishing with F1000Research:

- Your article is published within days, with no editorial bias

- You can publish traditional articles, null/negative results, case reports, data notes and more

- The peer review process is transparent and collaborative

- Your article is indexed in PubMed after passing peer review

- Dedicated customer support at every stage

For pre-submission enquiries, contact research@f1000.com 